\title{
Growth and Reproductive Activity of a Captive Female Harbour Porpoise (Phocoena phocoena) from Japanese Water
}

\section{Kazutoshi Arai, ${ }^{1,2}$, Gen Nakamura², Yoshiaki Maeda1, Etsuko Katsumata', Hiroshi Katsumata1, Kazuyoshi Taya ${ }^{3}$, Hidehiro Kato ${ }^{2}$}

\author{
${ }^{1}$ Kamogawa Sea World, Higashi-cho, Kamogawa, Chiba, Japan \\ ${ }^{2}$ Tokyo University of Marine Science and Technology, Konan, Minato, Tokyo, Japan \\ ${ }^{3}$ International Marine Biological Research Institute, Kamogawa Sea World, Higashi-cho, Kamogawa, Chiba, Japan \\ Email: kazutoshi_arai@granvista.co.jp
}

How to cite this paper: Arai, K., Nakamura, G., Maeda, Y., Katsumata, E., Katsumata, H., Taya, K. and Kato, H. (2017) Growth and Reproductive Activity of a Captive Female Harbour Porpoise (Phocoena phocoena) from Japanese Water. Open Journal of Animal Sciences, 7, 305-314. https://doi.org/10.4236/ojas.2017.73024

Received: June 7, 2017

Accepted: July 11, 2017

Published: July 14, 2017

Copyright $\odot 2017$ by authors and Scientific Research Publishing Inc. This work is licensed under the Creative Commons Attribution International License (CC BY 4.0).

http://creativecommons.org/licenses/by/4.0/

\begin{abstract}
This report describes growth and annual reproductive cycle of female harbour porpoise (Phocoena phocoena) rescued from Japanese water in 2007. The maximum body length was $179 \mathrm{~cm}$ and body weight was $69.8 \mathrm{~kg}$. The average daily food consumption was $7.0 \mathrm{~kg}$ (ranging $3.7-9.9 \mathrm{~kg}$ ), $11.8 \%$ of the body weight. In this report, the porpoise was kept in $17^{\circ} \mathrm{C}$ water annually and the blubber thicknesses showed almost constant throughout the year (average 18 $\mathrm{mm}$, range $13-22 \mathrm{~mm}$ ). Therefore, we added new evidence to this hypothesis by showing that body weight and the blubber thickness do not fluctuate seasonally in fixed water temperature. Serum progesterone level of the female showed five peaks from September to November, and each cycle lasted the average of 20.5 days. Such result indicates that harbour porpoise exhibits seasonal polyestrous activity.
\end{abstract}

\section{Keywords}

Harbour Porpoise, Female, Growth, Reproductive Activity, Japanese Water

\section{Introduction}

The harbour porpoises (Phocoena phocoena) are one of the smallest cetaceans distributed in cold waters of the North Atlantic and the North Pacific. Total body lengths of perinatal and mature animals vary within each population and female is larger than male in all populations [1]. Recently, there were reports of growth, energy intake and reproduction of harbour porpoise kept in a seminatural outdoor pool in Denmark [2] [3] [4]. These reports added some basic in- 
sights to the current information regarding growth and reproductive physiology by collecting data on individuals for a long term.

Harbour porpoise in Japan is distributed in the waters from Hokkaido to the northern coast of Honshu island and southern limit of the species distribution in the western Pacific is Wakayama, Japan $\left(34^{\circ} \mathrm{N}\right)$ [5]. Harbour porpoise is unlikely to be distributed in the further south on the west coast of Japan than Tsugaru Strait and the western extremity of Hokkaido in the summer, where the surface temperature is $12^{\circ} \mathrm{C}$ to $16^{\circ} \mathrm{C}$. Progression of seasonal reoccupation of northern waters in the western North Pacific is not well understood [5]. Researches on harbour porpoise in Japan are focused on their distribution utilizing genetic analyses [6], diving physiology [7] and sound production [8]. There are few studies about growth, reproductive activity in Japanese water [9]. According to the recent study using by catch records in Japanese waters, the birth month of obtained fetus in the study was estimated to be August [10].

To add some data for harbor porpoise in Japanese waters, this report describes growth, food intake and reproductive activity by analyzing serum progesterone levels of female harbour porpoise rescued by Kamogawa Sea World for the purpose of research under the approval of Japanese Fisheries Agency respectively.

\section{Materials and Methods}

\subsection{Animal and Research Period}

The porpoise was by catched in Chiba Prefecture, Pacific Coast of Honsyu Island in February 12, 2007, in a set net in Kamogawa, Chiba prefecture, Japan, $35^{\circ} 04 \mathrm{~N}$, $140^{\circ} 08 \mathrm{E}$ (Figure 1) with sardine (Sardinops melanostictus). The water temperature was $15.3^{\circ} \mathrm{C}$. The female porpoise was rescued after it was caught in a set net with no other porpoises. The body length and body weight at rescue was $163 \mathrm{~cm}$ and $55 \mathrm{~kg}$ respectively. Profile of the porpoise is shown in Table 1. The length of this research period was four years.

\subsection{Keeping Facility, Environment, and Cohabitant Animals}

The porpoise was initially kept in an outdoor facility with two female white sided dolphins (Lagenorhynchus obliquidens). The water is disinfected natural sea water, average water temperature was $19.6^{\circ} \mathrm{C}$ and the size of the pool was 347 $\mathrm{m}^{3}$. The porpoise was later relocated to an indoor beluga exhibition facility 21 days after acquisition. This particular pool was considered to be the most suitable

Table 1. Profile of the porpoise when it was rescued.

\begin{tabular}{cc}
\hline Date of rescue & February 12, 2007 \\
Sex & Female \\
Body length & $163 \mathrm{~cm}$ \\
Body weight & $55 \mathrm{~kg}$ \\
Cite of rescue & $35^{\circ} 04 \mathrm{~N}, 140^{\circ} 08 \mathrm{E}$ \\
Water temperature & $15.3^{\circ} \mathrm{C}$ \\
\hline
\end{tabular}




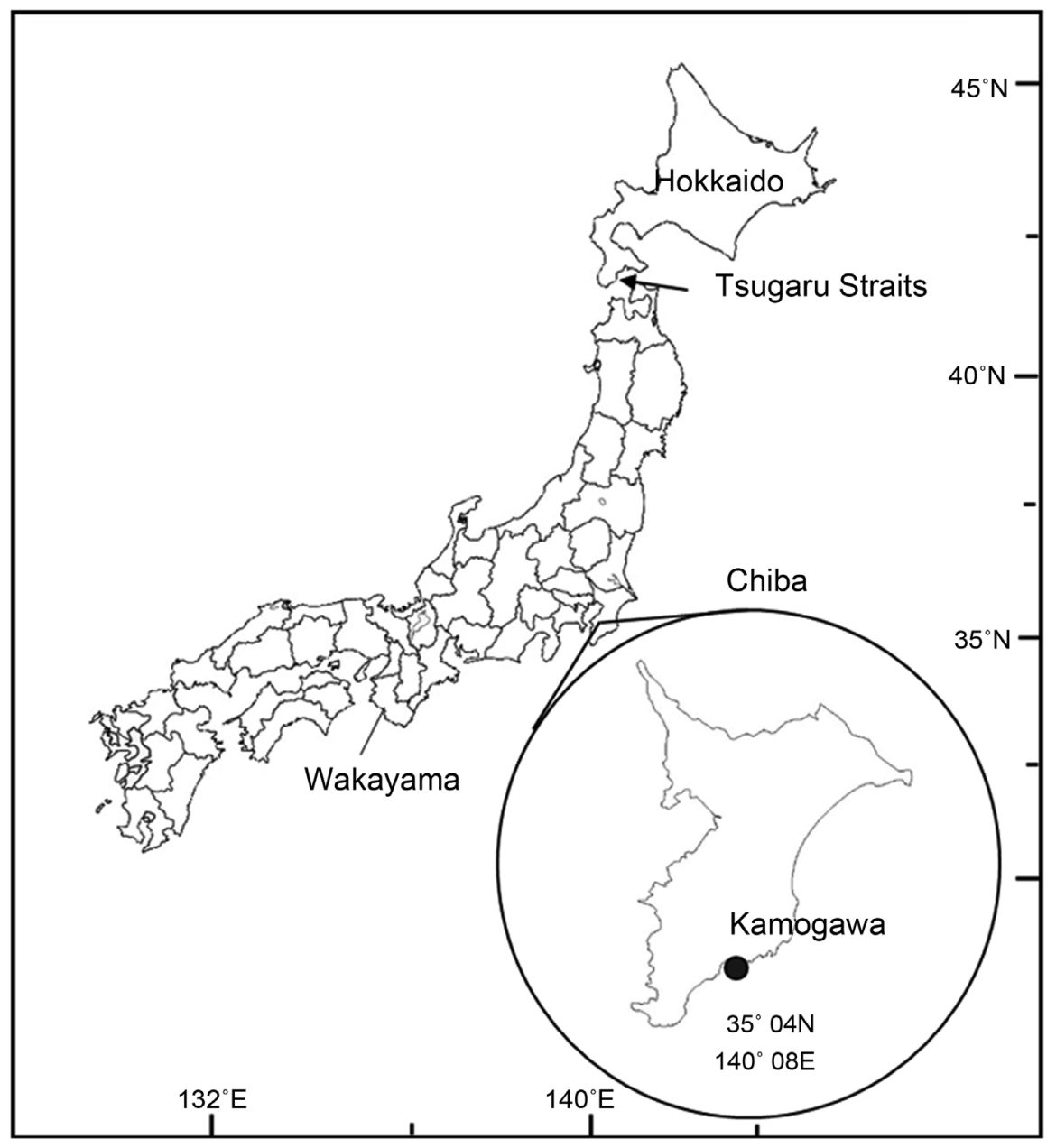

Figure 1. Cite of rescue (Kamogawa, Chiba prefecture, Japan).

for the animal due to its cooler water temperature. There were three belugas (Delphinapterus leucas) (two males and one female) kept in the same pool (Figure 2(B)). The indoor facility consists of $603 \mathrm{~m}^{3}$ exhibition pool and $230 \mathrm{~m}^{3}$ back up pool which are connected via water gate. The water is disinfected natural sea water and the temperature was maintained at $17.5^{\circ} \mathrm{C} \pm 0.5^{\circ} \mathrm{C}$ throughout the year. The day length was kept the same as the day length of $35^{\circ} 04 \mathrm{~N}, 140^{\circ} 08 \mathrm{E}$ where the facility is located. Feeding took place four-six times a day by standing hand feed (Figure $2(\mathrm{C})$ ). The porpoise was fed with smelt (Mallotus villosus) and horse mackerel (Trachurus japonicus).

\subsection{Monitoring Method}

Age estimate: Gompertz growth curve fit to length at age data for female from stranding record in Japan [11].

Body length and body weight. The body length and the body weight were measured every one to two months at the poolside (Figure 2(D)).

Girth and blubber thickness measurements. Girth was measured at the caudal edge of dorsal fin, which is referred to as mid-girth or G3 by Lockyer et al. (2003), every one to two months (Figure 2(E)). The blubber thickness was 


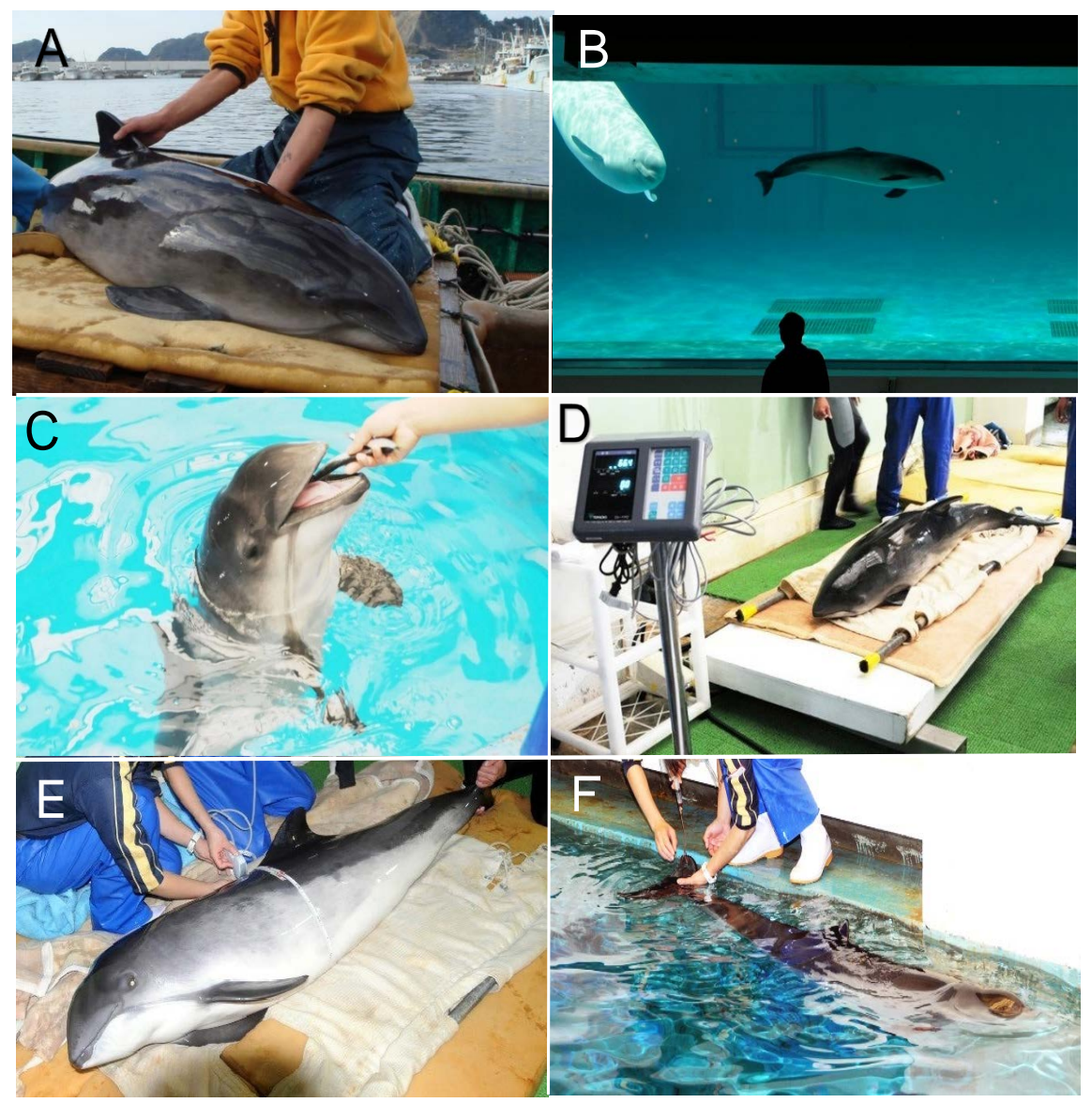

Figure 2. (A): Porpoise on the boat immediately after the rescue. (B): Indoor exhibition pool where the animal was mainly housed with belugas. (C): Feeding was done by standing-hand-feed. (D): Body weight was taken at the pool side. (E): Measuring girth and blubber thickness utilizing ultrasonography. (F): Porpoise cooperating for husbandry blood draw.

measured every one to two months in November 2008 to December 2009, it was measured dorsally, at the same point where mid-girth was measured [3] by means of a portable ultrasonography (Micro Maxx, Sonosite) in 2010 (Figure 2(E)).

Progesterone: The serum progesterone levels were measured every one to four weeks by husbandry blood draw. Blood was collected from the tail fluke vessels voluntarily (Figure $2(\mathrm{~F})$ ) and was transferred into a vacuum blood sampling tube (Venoject, Autosep, Terumo, Tokyo, Japan). After centrifugation at $1700 \mathrm{~g}$ for $10 \mathrm{~min}$ at room temperature, serum was kept at $-20^{\circ} \mathrm{C}$ until progesterone assay was performed. The serum progesterone levels were measured by the no-extraction tube stationary phase method $\left(\right.$ COAT-COUNT $\left.^{\oplus}\right)$ using a DPC Progesterone Kit (Daiichi Pure Chemical Co., Ltd. Tokyo, Japan) The intra-and inter-assay coefficients of variation were $4.2 \%$ and $6.8 \%$, respectively. The low limits of the assay sensitivity were $0.1 \mathrm{ng} / \mathrm{ml}$. All procedures were carried out in accordance with the guidelines established by Kamogawa Sea World. 


\section{Results}

Age at rescue: The porpoise was estimated to be five years of age when rescued. Estimated age was calculated from Gompertz growth curve obtained from cross-sectional length at each age. The data for this curve was obtained from collective data of stranded females. From following equation;

$$
B L=170.589 e^{-0.93 e^{-0.58 t}}
$$

Body length, body weight and Girth: Figures 3(A)-(C) shows the change in the body length, the body weight and the girth for four years. Initial body length at rescue in 2007 (age 5) was $163 \mathrm{~cm}$. Over 29 months, animal grew $16 \mathrm{~cm}$ as it reached its physical maturity. The body weight was $55 \mathrm{~kg}$ at rescue, and reached physical maturity at $69.8 \mathrm{~kg}$ in December 2009 (age 7). The mid-girth was $86 \mathrm{~cm}$ at the rescue, and reached the maximum at $96 \mathrm{~cm}$ in March 2009 (age 7).
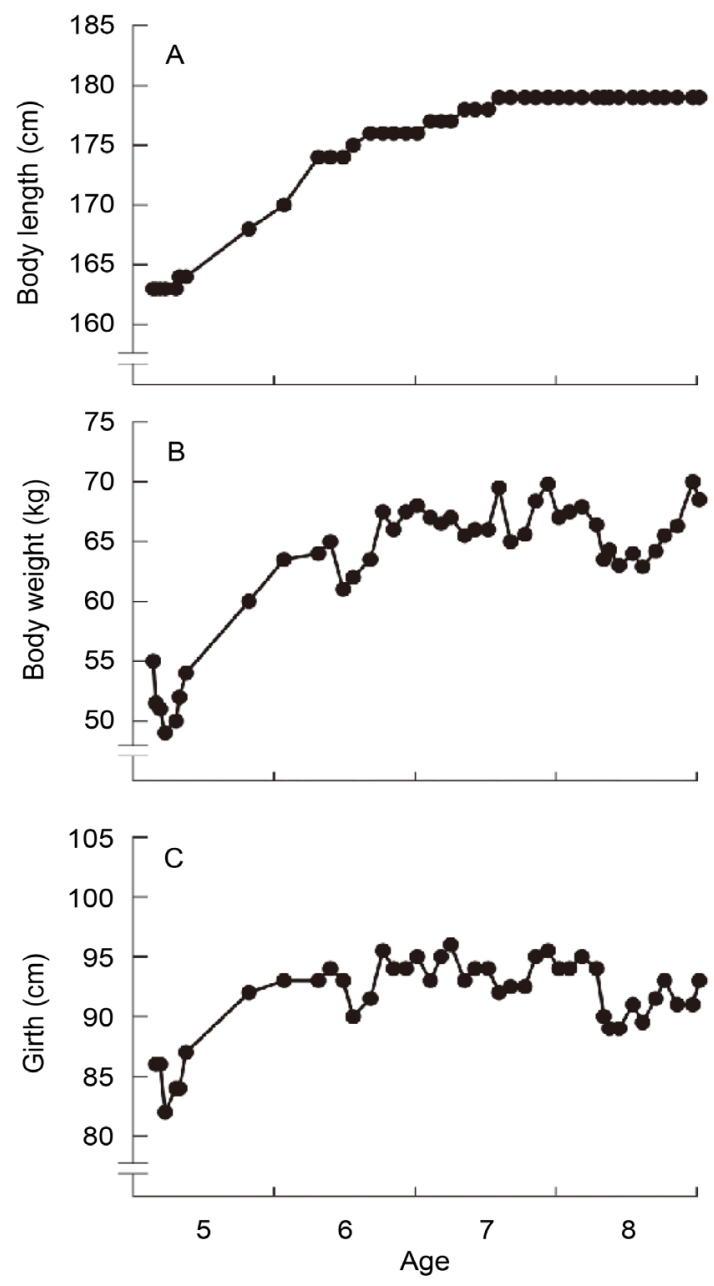

Figure 3. (A): Change in body length over a period of four years (2007-2010). Initial body length at rescue in 2007 (age 5) was $163 \mathrm{~cm}$. Over 29 months animal grew $16 \mathrm{~cm}$ as it reached its physical maturity. (B): Change in Body weight over a period of four years (2007-2010). The body weight was $55 \mathrm{~kg}$ at rescue, and reached physical maturity at $69.8 \mathrm{~kg}$ in December 2009 (age 7). (C) The mid-girth was $86 \mathrm{~cm}$ at the rescue and reached the maximum at $96 \mathrm{~cm}$ in March 2009 (age 7). 
Blubber thickness: Blubber thickness fluctuated between 13 and $22 \mathrm{~mm}$, average $18 \mathrm{~mm}$ within a year. No correlation was found between blubber thickness and girth (Spearman rank relation test, $r=0.29, P=0.42$ ) nor between blubber thickness and body weight (Pearson's correlation coefficient test, $r=0.47, P=$ $0.2)$.

Food consumption: Figure 4(A) shows the daily average food. Food consumption was increased for the first month since acquisition as the animal was adapting to the new environment, then it was constant around 7 to $8 \mathrm{~kg}$. The food consumption was decreased to $5 \mathrm{~kg}$ due to digestive disorder at the age of 8 . Figure 4(B) shows food consumption as percentage of body weight was $11.8 \%$ on the average, tended to decrease after marking the maximum of $16 \%$.

Serum progesterone: Serum progesterone concentration was sampled regularly. The changes in the serum progesterone are shown in Figure 5. On August 28,2008 , the concentration was $2.3 \mathrm{ng} / \mathrm{ml}$ with a rapid increase up to $9.1 \mathrm{ng} / \mathrm{ml}$ on September 29. In 2009, there was no such increase observed, and the concentration stayed low as $0.1-1.3 \mathrm{ng} / \mathrm{ml}$ throughout the year. In 2010, the serum progesterone level stayed at basal value from January to August, and then started

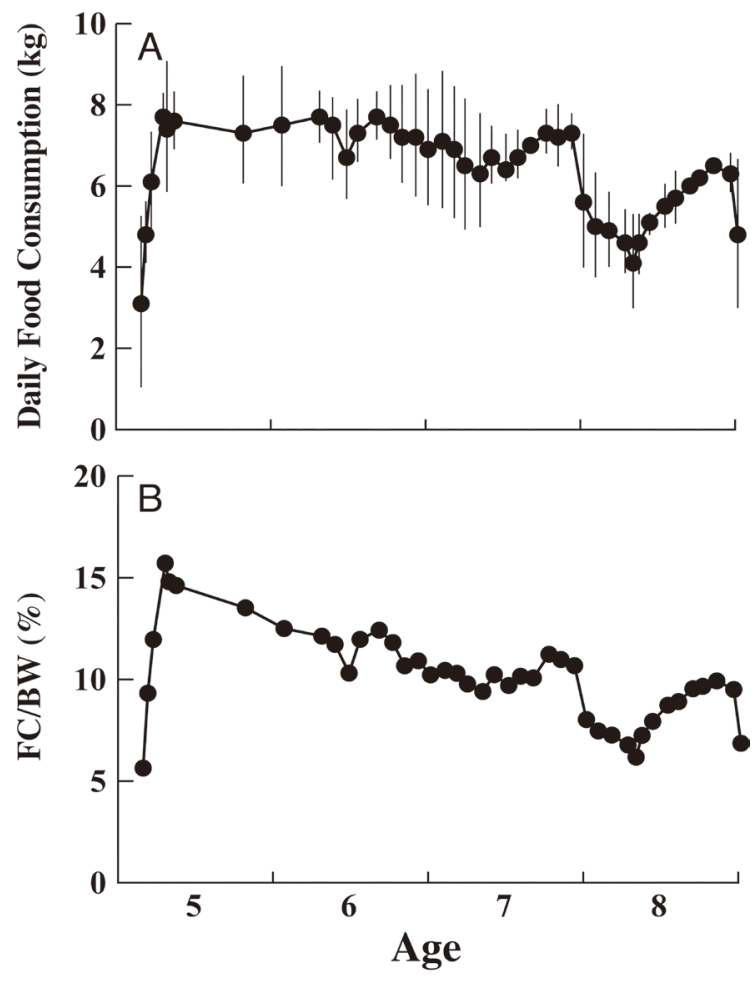

Figure 4. (A): Change in average daily consumption. It was increased during the time of adaptation for the first month, then kept at a constant amount of 7 to $8 \mathrm{~kg}$. In 2010, the food consumption decreased due to digestive disorder at the age of 8.Each bar represents SD. (B): Food consumption as a percentage of body weight. It was increased during the first month of adaptation period, then after marking a maximum rate of $16 \%$, it was slowly decreased. 
to cycle in September (Figure 6). The peaks of each cycle were observed 5 times from September to November. Each cycle lasted 18 - 23 days, which is 20.5 days on average. The progesterone level decreased to the basal value in November.

\section{Discussion}

According to research conducted with 14 populations in the North Atlantic and 10 populations in the North Pacific [12], it is known that body size of porpoises is different in each population. One study done in Japan with 16 porpoises reported that one pregnant female was $166 \mathrm{~cm}$ and one neonate with the navel cord attached was $92.4 \mathrm{~cm}$ [13]. The porpoise in this study has reached its physical maturity as it reached a plateau at $179 \mathrm{~cm}$ in 2009 (age 7). Additionally, Ishikawa [11] and Taguchi et al. [10] reported the maximum female

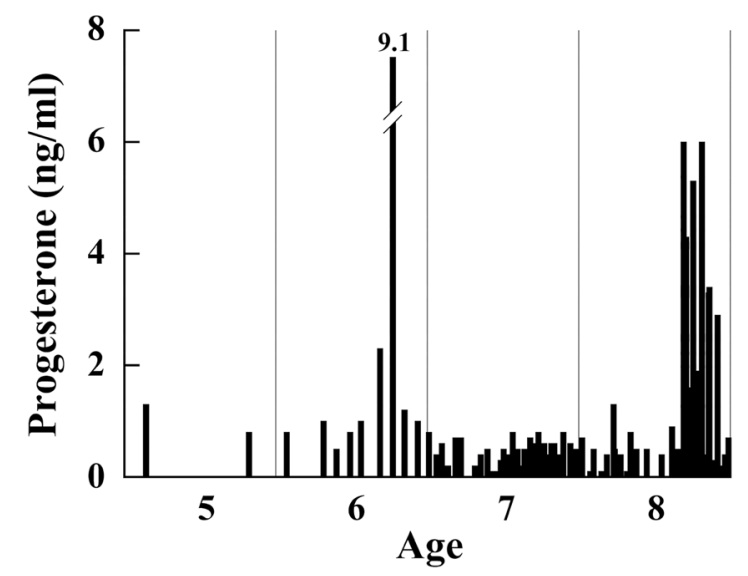

Figure 5. Change in serum progesterone levels from age 5 to 8 . Increase in serum progesterone concentration was observed in late summer at the age of 6 and 8 . Measurement was two times at age 5, seasonal change was unknown.

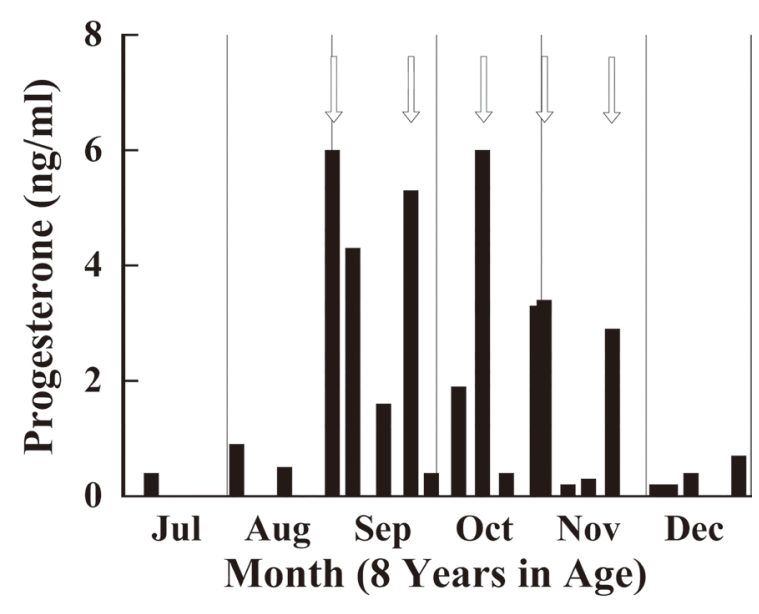

Figure 6. Serum progesterone concentration during the month of July and December at the age of 8 . Five peaks were observed with the average of 20.5 days apart. White arrows show peak of progesterone levels of each cycle. 
length of $185 \mathrm{~cm}$. The mature body lengths of porpoises in Japanese water were larger than that of populations in the North Atlantic [3].

\subsection{The Changes of the Weight and Blubber Thickness}

The body weight has shown linear increase following the temporal decrease immediately after the rescue. Since 2009 (age 7), the body weight remained around 65 - $70 \mathrm{~kg}$. Porpoises kept in a semi-natural pool in Denmark showed that seasonal fluctuations of body weight, girth, and blubber thickness in the water temperature of the pool was $3^{\circ} \mathrm{C}-18^{\circ} \mathrm{C}$ [3]. On the other hand, the porpoise in this study was kept in $17^{\circ} \mathrm{C}$ water annually, which was equivalent with relatively warmer temperature period of their natural habitat. The blubber thickness measured at the same parts was $13-22 \mathrm{~mm}$ although no seasonal fluctuation was observed. These results illustrate that thickness of blubber fluctuates according to the water temperature; however these fluctuations do not seem to occur in fixed warm water temperature.

\subsection{Food Consumption}

The daily food consumptions was $7.0 \mathrm{~kg}$ on average, which is $11.8 \%$ of the body weight with no seasonal changes. Captive porpoises have been reported to grow with food intake of $10 \%$ of the body weight [3]. In the study in Denmark, the food consumption changed seasonally. The food consumption increased rapidly in July, and decreased soon after January. The body weight also changed in the same manner 2 - 3 months after the change of the food consumption occurred [3]. Tobayama [14] reported that porpoises kept in captivity started to lose weight in water temperature higher than $20^{\circ} \mathrm{C}$ and kept decreasing inversely to the water temperature in the spite of increase in food consumption. These results show that it is important to take into account water temperature, activity budget, the size and the species in the diet, and appetite, comprehensively.

\subsection{Changes of Blood Progesterone Concentration and the Reproductive Season}

There was an increase of serum progesterone in August and September 2008 (age 6), which indicates that she was in the luteal (post-ovulatory) phase. The similar increase was also observed from September to November in 2010 (age 8). Previous research focused on captive small odontocetes revealed that some species of exhibit seasonal polyestrous cycle, in other words, they go through multiple hormonal cycles within one breeding season. Each cycle can be identified by endocrinological analysis such as progesterone monitoring [15]. With the result of the current study, it can be assumed that harbor porpoises follow a similar trend with the rest of the small odontocetes mentioned by O'Brien and Robeck [15]. While breeding season, serum progesterone concentration exhibits multiple peaks, though at the point when one conceive with a calf, serum progesterone concentration tends to remain at a high concentration.

It is known that porpoises in the Atlantic Ocean mate in the summer (July to 
September) and their calving season is early summer (June to August) after 11 months of gestation period [16] [17]. However, little is known about the precise mating season of porpoises in Japanese waters, since they migrate towards the North Pacific Ocean as water temperature increases. This study therefore provides a significant insight for better understanding basic reproductive season of female porpoises in the Japanese waters.

Since the water temperature was constant throughout the year, the reproductive season of porpoise is highly likely to be affected by day length. In 2010 (age 8), blood samples were collected weekly, and observed five cycles within 20.5 days. This multi-peaked increase clearly shows that porpoise have seasonal polyestrous activity. In 2009 (age 7), weekly blood sampling was carried out to investigate the details of the reproductive cycle, although there was no increase in serum progesterone level throughout the year. Yoshioka et al. [18] also reported the case of captive bottlenose dolphins not exhibiting estrous cycle in certain year. Possible cause not cycling in 2009 was not able to be determined with this study, however a similar mechanism as bottlenose dolphins' case previously mentioned may have worked. It can be assumed that reproductive season observed in current study showed annual cycle.

From analyzing birth month of stranding records, Taguchi [10] concluded the parturient season of harbour porpoise in Japan was estimated to be August instead of May to June. Thus this supports our data that serum progesterone concentration of harbour porpoise increased in August and September. It is necessary to collect additional cases to obtain more data sets that should lead to more accurate conclusion.

\section{Acknowledgements}

The authors thank the veterinary and training staff at Kamogawa Sea World for their consistent support to take data necessary to make this possible, and Kaori Fukatsu for English support. We also thank Dr. Christina Lockyer for editorial comments.

\section{References}

[1] Read, A. (1999) Harbour Porpoise Phocoena phocoena (Linnaeus, 1758). In: Ridgway, S.H. and Harrison, R., Eds., Handbook of Marine Mammals, Volume 6: The Second Book of Dolphins and the Porpoises, Academic Press, Cambridge, 323-355.

[2] Deportes, G., Kristensen, J.H., Benham, D., Wilson, S., Jepsen, T., Korsgaard, B. Siebert, U., Driver, J., Amundin, M., Hansen, K. and Shephard, G. (2003) Multiple Insights into the Reproductive Function of Harbour Porpoeses (Phocoena phocoena): An Ongoing Study. In: Haug, T., Desportes, G., Vikingsson, G.A. and Witting, L., Eds., Harbour Porpoises in the North Atlantic, NAMMCO Scientific Publications Vol. 5.,Tromso, 91-105.

[3] Lockyer, C., Desportes, G., Hansen, K., Labberté, S. and Siebert, U. (2003) Monitoring Growth and Energy Utilization of the Harbour Porpoise (Phocoena phocoena) in Human Care. In: Haug, T., Desportes, G., Vikingsson, G.A. and Witting, L. Eds., Harbour Porpoises in the North Atlantic, NAMMCO Scientific Publications Vol. 5.,Tromso, 107-120. 
[4] Blanchet, M.A., Nance, T., Colleen, A., Wahlberg, M. and Acquarone, M. (2008) First Case of a Monitored Pregnancy of a Harbour Porpoise (Phocoena phocoena) under Human Care. Aquatic Mammals, 34, 9-20.

https://doi.org/10.1578/AM.34.1.2008.9

[5] Gaskin, D.E., Yamamoto, S. and Kawamura, A. (1993) Harbor Porpoise, Phocoena phocoena (L.), in the Coastal Waters of Northern Japan. Fishery Bulletin, 91, 440454.

[6] Taguchi, M., Chivers, S.J., Rosel, P.E., Matsuishi, T. and Abe, S. (2010) Mitochondrial DNA Phylogeography of the Harbour Porpoise Phocoena phocoena in the North Pacific. Marine Biology, 157, 1489-1498. https://doi.org/10.1007/s00227-010-1423-7

[7] Otani, S., Naito, Y., Kato, A. and Kawamura, A. (2001) Oxygen Consumption and Swim Speed of the Harbor Porpoise Phocoena phocoena. Fisheries Science, 67, 894898. https://doi.org/10.1046/j.1444-2906.2001.00338.x

[8] Nakamura, K., Akamatsu, T., Simazaki, K. (1998) Threat Clicks of Captive Habour Porpoises (Phocoena phocoena). Bulletin of the Faculty of Fisheries, Hokkaido University, 49, 91-105.

[9] Honma, Y., Ushiki, T., Hashizume, H., Takeda, M. Matsuishi, T. and Honno, Y. (2004) Histological Observations on the Reproductive Organs of Harbor Porpoises Phocoena phocoena Incidentally Caught in a Set Net Installed off Usujiri, Southern Hokkaido. Fisheries Science, 70, 94-99. https://doi.org/10.1111/j.1444-2906.2003.00776.x

[10] Taguchi, M., Ishikawa, H. and Matsuishi, T. (2010) Seasonal Distribution of Harbour Porpoise (Phocoena phocoena) in Japanese Waters Inferred from Stranding and Bycatch Records. Mammal Study, 35, 133-138. https://doi.org/10.3106/041.035.0204

[11] Ishikawa, H., Goto, M. and Mogoe, T. (2013) Stranding Record in Japan (19012012). Shimonoseki Marine Science Report, 1, 1-314. (In Japanese)

[12] Jefferson, T.A., Webber, M.A. and Pitman, R.L. (2008) Marine Mammals of the World. A Comprehensive Guide to Their Identification. Academic Press, Amsterdam, $573 \mathrm{p}$

[13] Miyazaki, N., Amano, N. and Fujise, Y. (1987) Growth and Skull Morphology of the Harbour Porpoises in the Japanese Waters. Memoires of the Natural Science $\mathrm{Mu}$ seum of Tokyo, 20, 137-146. (In Japanese)

[14] Tobayama, T. (1974) Ribbon Seal (Histriophoca fasciata) and Harbour Porpoise (Phocoena phocoena) in Kamogawa Sea World. 28 th International Union of Directors of Zoological Gardens, 13-20. (In Japanese)

[15] O’Brien, J.K. and Robeck, T.R. (2010) The Value of ex Situ Cetacean Populations in Understanding Reproductive Physiology and Developing Assisted Reproductive Technology for ex Situ and in Situ Species Management and Conservation Efforts. International Journal of Comparative Psychology, 23, 227-248.

[16] Gaskin, D.E., Smith G.J.D., Watson, A.P., Yasui, W.Y. and Yurick, D.B. (1984) Reproduction in the Porpoises (Phocoenidae): Implication for Management. Report of the International Whale Commission, Special Issue 6, 135-148.

[17] Blanchet, M.A., Wahlberg, M. and Ishigami, T. (2009) First Observation of the Parturition and Peripartum Events in a Harbor Porpoise (Phocoena phocoena). Aquatic Mammals, 35, 473-480. https://doi.org/10.1578/AM.35.4.2009.473

[18] Yoshioka, M., Mohri, E., Tobayama, T., Aida, K. and Hanyu, I. (1986) Annual Changes in Serum Reproductive Hormone Levels in the Captive Female BottleNosed Dolphin. Nippon Suisan Gakkaishi, 52, 1939-1946.

https://doi.org/10.2331/suisan.52.1939 
Submit or recommend next manuscript to SCIRP and we will provide best service for you:

Accepting pre-submission inquiries through Email, Facebook, LinkedIn, Twitter, etc. A wide selection of journals (inclusive of 9 subjects, more than 200 journals)

Providing 24-hour high-quality service

User-friendly online submission system

Fair and swift peer-review system

Efficient typesetting and proofreading procedure

Display of the result of downloads and visits, as well as the number of cited articles Maximum dissemination of your research work

Submit your manuscript at: http://papersubmission.scirp.org/

Or contact ojas@scirp.org 